\title{
The Effect of Anastatica hierochuntica L. Extract on the Histology of Myometrial Cells and Prostaglandin Levels (PGE2, PGF2 $\alpha$ ) in Pregnant Mice
}

\author{
Heny Astutik ${ }^{1, *}$, Budi Santoso ${ }^{2}$, Mangestuti Agil ${ }^{3}$ \\ ${ }^{1}$ Department of Midwifery, Poltekkes Kemenkes Malang, Malang, Indonesia \\ ${ }^{2}$ Department of Medicine Science, Faculty of Medicine, Universitas Airlangga, Surabaya, Indonesia \\ ${ }^{3}$ Department of Pharmacognosy and Phytochemistry, Faculty of Pharmacy, Universitas Airlangga, Surabaya, Indonesia \\ *Corresponding author. Email: henyast21@gmail.com
}

\begin{abstract}
Anastatica hierochuntica $\mathrm{L}$. is well known as a traditional medicine which brings benefit to the final trimester of pregnancy by increase uterine contractions. This study aimed to analyze the effect of A. hierochuntica $\mathrm{L}$. extract on the histology of myometrial cells and prostaglandin levels (PGE2 and PGF2 $\alpha$ ) of pregnant mice. The mice were divided into three groups: (1) control group, treated by $0.5 \% \mathrm{CMC}$ solution $10 \mathrm{ml} / \mathrm{kg}$ bw/day; (2) two treatment groups that treated by A. hierochuntica L. extract with 100 and $150 \mathrm{mg} / \mathrm{kg}$ bw/day doses, respectively. Uterine tissue was collected for histological analysis and blood serum was collected to examine the PGE2 and PGF2 $\alpha$ levels. It obtained that myometrial hypertrophy increased significantly in the treatment groups $(\mathrm{p}=0.001)$ than in the control group. Moreover, there were significant differences in the PGE2 levels $(p=0.001)$ and PGF2 $\alpha$ levels $(p=0.000)$ between the control group and the treatment groups. The $100 \mathrm{mg} / \mathrm{kg}$ bw/day dose had a greater effect on myometrial hypertrophy than $150 \mathrm{mg} / \mathrm{kg}$ bw/day, which resulted in a higher increase of PGE2 and PGF2 $\alpha$ levels. Hence, it was concluded that the $100 \mathrm{mg} / \mathrm{kg}$ bw/day dose of $A$. hierochuntica $\mathrm{L}$. extract was the appropriate dose for increasing prostaglandin levels.
\end{abstract}

Keywords: Anastatica hierochuntica L., myometrial cells, prostaglandins, pregnant mice

\section{INTRODUCTION}

Nowadays, advanced technology and medical science still utilizing plant-based medicines [1]. Herbal medicine is considered safe since they are derived from natural products and has fewer side effects. In brief, herbal medicines are mostly utilized in developing countries for routine health care [2] and treatment of gynecological health issues, including Indonesia [3]. A.hierochuntica L. is well known as a traditional medicine and in Indonesia, it has been extensively consumed by expectant mothers during the final trimester of their pregnancy to increase uterine contractions to initiate labor. Indonesian pregnant women used to drink the soaking water of A. hierochuntica L [4]. Nevertheless, there is no much research about the biological activity of this plant.

A. hierochuntica L., also known as Rose of Jericho, Fatimah grip, [5] Kaff Maryam-or in Indonesia-as Rumput Fatimah, is found in the Sahara-Arab desert where it is widely consumed as an herbal tea drink [6]. It was claimed to be very useful in the antepartum treatment [6] and has been used as a traditional medicine during the end of pregnancy, since it is popularly believed to facilitate the delivery process, [5] reduces uterine bleeding, [7] and treats various health problems [2][6][8][9]. Based on pharmacology studies, A. hierochuntica L. contains phenolic substances $(51.97 \mathrm{mg} / \mathrm{g} \mathrm{d} . \mathrm{w})$, flavonoids (42.53 to $46.28 \mathrm{mg} / \mathrm{g} \mathrm{d} . \mathrm{w}) 10$, sterol11, and several minerals including $\mathrm{Mg}, \mathrm{Ca}, \mathrm{Cr}, \mathrm{Mn}, \mathrm{Fe}, \mathrm{Co}, \mathrm{Cu}$ and $\mathrm{Zn} .9$ A. hierochuntica L. is considered a phytoestrogen plant, with estrogenic activity, due to the presence of flavonoids and another compound.9,11-14 Phytoestrogen-a member of the polyphenols family - is derived from herbal and it functions similar to estrogen in the human reproductive system [15]. A study by Nani [4] resulted that drinking the soaking water containing a dose of 40 grams of A. hierochuntica L. increased the frequency of uterine contractions [4]. However, until now, the mechanism that regulates myometrial contraction activity during pregnancy, labor, and birth has not been fully observed [16]. Several studies have obtained an overview of the estrogenic effect of phytoestrogens [17]. The uterine tissue undergoes changes in histological structure that are dynamic based on estrogen levels [18]. Estrogen also increases a series of myometrial changes, including elevated production of the prostaglandins, PGE2 and PGF2 $\alpha$, with a high expression of prostaglandin receptors [19].

Prostaglandins, especially those produced in intrauterine tissue, play a central role in the initiation and development of labor, including myometrial contraction stimulation, metabolism management of the extracellular matrix related to cervical maturation, and upregulation of the fetal HPA- 
axis [20]. Prostaglandin (PGs), a uterotonic agent [21] and a stimulator of uterine contractions [3] is synthesized from arachidonic acid by cyclooxygenases and prostanoid synthases [22]. Prostaglandins act by binding to certain G protein-coupled receptors [23] thereby activating intracellular signals and gene transcription [24].

In addition to having estrogenic activity, $A$. hierochuntica L. also has gastroprotective activity, [13] hepatoprotective activity, [24] antioxidants activity [9]. Several studies have been conducted to identify the various activities of this plant, but only a few studies are available regarding the histological effects of $A$. hierochuntica $\mathrm{L}$. and its activity during labor. Ethnobotany research aims to investigate and report the herbs for gynecological health problems and their uterotonic activities in several countries, including Indonesia [3]. However, studies related to the biological activity of $A$. hierochuntica $\mathrm{L}$. during labor have not been reported. Therefore, this study aimed to evaluate the effect that $A$. hierochuntica $\mathrm{L}$. has on histological changes in myometrial cells and prostaglandin levels (PGE2, PGF2a) in pregnant mice. Understanding the histological effects of this herb is essential since, in many cases, there is no scientific evidence on the use of A. hierochuntica L. plants as a facilitator of labor during childbirth.

\section{METHOD}

The material used in this study is the whole A. hierochuntica L. was obtained from the local market of Saudi Arabia. This plant determined by plant taxonomists from the Indonesian Institute of Science (LIPI), Plant Conservation Center of Bogor and it has also been identified using the liquid chromatography-mass spectrometry (LCMS) method.

The plant was extracted with $96 \%$ ethanol using maceration method. The sample was sonicated in an ultrasonic bath for 10 minutes, then filtered, using a Burger funnel which was connected to a vacuum pump to obtain residue and solution. The solution obtained from each filtration step was evaporated using a rotary evaporator at $50{ }^{\circ} \mathrm{C}$. Furthermore, the extract was weighed and stored in a closed bottle at 4 ${ }^{\circ} \mathrm{C}$.

The research protocol for this study was approved by the local ethics committee. Healthy adult female mice (Mus musculus strain Balb C), 12-14 weeks old and 25-35 grams in weight, were used for this research. The mice were acclimated for a week then their estrus period was synchronized using $5 \mathrm{IU} 0.1 \mathrm{~mL}$ of Prostaglandin and $5 \mathrm{IU}$ $0.1 \mathrm{~mL}$ of HCG. Afterward, the female mice were placed with fertile male mice, 1:1 (monogamy), for breeding.

All pregnant mice were divided into three groups - the control group (P0) and two treatment groups (P1 and P2). Each group consisted of seven random mice. Treatment was treated on day 14 to 18 of pregnancy. Mice within the control group were treated by $0.5 \% \mathrm{CMC}$ Na solution 10 $\mathrm{mL} / \mathrm{kg}$ bw/day for 5 days. Mice belonged to P1 and P2 treatment groups were treated by $A$. hierochuntica $\mathrm{L}$. extract, 100 and a $150 \mathrm{mg} / \mathrm{kg}$ bw/day dose of, respectively, for 5 days. On the 19th day, mice were dislocated for the preparation of uterine organ tissue and blood serum collection.
The fetus was removed from the uterus, then one side of the uterine cornu was excised, fixed in a $10 \%$ formalin buffer solution for 24 hours, and planted in paraffin. The tissue was stained with Hematoxylin-Eosin (HE staining) and the staining results were observed using a Nikon H600L microscope with a DS Fi2 300 megapixel of a digital camera. The Examination of prostaglandin levels, PGE2 and PGF2 $\alpha$, were measured in intracardiac blood serum of pregnant mice using a sandwich ELISA kit.

All the myometrial cell histology for each sample was assessed semiquantitatively according to the modified Billingham method [25]. The myometrial cell histology was measured within a 0-5.5 score based on histological changes, which was a percentage of hypertrophic myocytes of all observed myocytes. The hypertrophic cells were determined based on the size or diameter of myocyte cells, which more than $6 \mu \mathrm{m}$.

The data were analyzed using the Kruskal Wallis test to identify the differences in myometrial histology. Moreover, a one-way ANOVA was conducted to analyze the prostaglandin level $(\mathrm{p}<0.05)$. Then, the post-hoc test with LSD was used to determine the differences between the treatments of each group.

\section{RESULTS AND DISCUSSION}

Myometrium is one of the essential reproductive organs that regulate contractions. This regulation is controlled by estrogen and progesterone. ${ }^{26}$ Estrogen has a direct or indirect ability to change the myometrium, as it increases the capacity of contraction power in myometrial cell hypertrophy ${ }^{27}$, the contractile potential of myometrium cells, uterotonic receptors, and cell to cell communication [21][28].

Table 1 shows the results of the microscopic examination of myometrium obtained from the uterine tissue of pregnant mice. This identification aimed to determine the hypertrophic degree of myometrial myocytes associated with an estrogenic activity of A.hierochuntica L. extract in pregnant mice. It was also expected to have an effect on prostaglandin production (PGF2a and PGE2). The alteration of myometrial cells is related to the administration of A. hierochuntica L. extract, as presented in Figure 1.
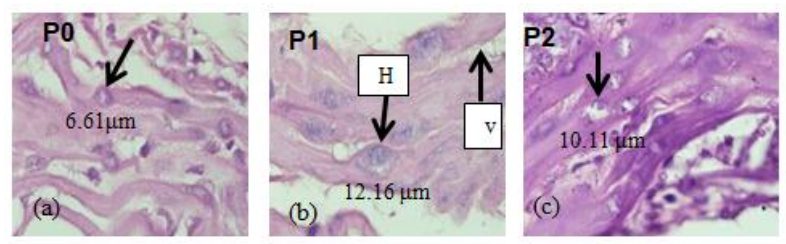

Figure 1. The size difference in the nucleus of hypertrophic myocyte cells (arrows) between treatment groups $(\mu \mathrm{m})$ : (a) Myometrial tissue of the control group (P0), (b) Myometrial tissue of the treated groups (P1) $(\mathrm{H}=$ hypertrophy; $\mathrm{V}=$ vacuolization), and (c) P2. (M=400x; Nikon microscope 6001; camera ds fi2 300 megapixels). 
The histological analysis of myometrium cells of pregnant mice treated with $100 \mathrm{mg} / \mathrm{kg}$ bw/day of A.hierochuntica $\mathrm{L}$. extract showed that there was an increasing number of hypertrophy cells $(\mathrm{H})$ with larger myocyte cell diameter compared to the control group and the treatment group treated $150 \mathrm{mg} / \mathrm{kg} /$ day of the extract (P2) (Figure 1).

Table 1. Microscopic Changes within Myometrial Myocytes Cells in Pregnant Mice Treated Different Doses of Anastatica hierochuntica L. (Ah) Extract

\begin{tabular}{|c|c|c|c|}
\hline Group & $\begin{array}{c}\text { Extract } \\
\text { dose/kgbw }\end{array}$ & $\begin{array}{l}\text { A hypertrophic } \\
\text { score of } \\
\text { myocyte cells }\end{array}$ & $\begin{array}{l}\text { Number of hypertrophic } \\
\text { myocyte cells }\end{array}$ \\
\hline $\begin{array}{l}\text { Group } 1 \\
\text { (P0) }\end{array}$ & $0 \mathrm{mg}$ & 0.71 & $\begin{array}{l}\text { The average number of } \\
\text { hypertrophic myocyte cells was } \\
<5 \% \text { of observed myocyte } \\
\text { cells }\end{array}$ \\
\hline $\begin{array}{l}\text { Group } 2 \\
\text { (P1) }\end{array}$ & $100 \mathrm{mg}$ & 3.43 & $\begin{array}{l}\text { The average number of } \\
\text { hypertrophic myocyte cells was } \\
36-50 \% \text { of observed myocyte } \\
\text { cells, whilst some of them had } \\
\text { the vacuolization }\end{array}$ \\
\hline $\begin{array}{l}\text { Group } 3 \\
\text { (P2) }\end{array}$ & $150 \mathrm{mg}$ & 2.79 & $\begin{array}{l}\text { The average number of } \\
\text { hypertrophic myocyte cells was } \\
36-50 \% \text { of observed myocyte } \\
\text { cells }\end{array}$ \\
\hline
\end{tabular}

* Group $1=$ control, pregnant mice were treated $0.5 \% \mathrm{CMC}$ solution, Group 2 = Pregnant mice treated with $\mathrm{AH}$ extract dose of $100 \mathrm{mg} / \mathrm{kg}$ bw/day, Group $3=$ Pregnant mice treated with AH extract dose of $150 \mathrm{mg} / \mathrm{kg}$ bw/day.

Table 1 shows that the average number of hypertrophic myocyte cells in the control group was $<5 \%$ of all observed myocytes cells, while in the pregnant mice group treated with A. hierochuntica L. (AH) extract, the number of hypertrophic myocyte cells increased up $36-50 \%$ both in the P1 and P2 groups - and some of the cells underwent vacuolization. The difference in the hypertrophic scores of the myometrial cells between the three groups of pregnant mice is shown in Table 2.

Table 2. The Results of the Hypertrophic Score of Myometrial Myocytes Cells in the Treatment Groups Treated Different Doses of Anastatica hierochuntica L. Extract.

\begin{tabular}{ccccccc}
\hline \multirow{2}{*}{ Group } & \multirow{n}{*}{} & \multicolumn{3}{c}{ The hypertrophic score of myometrial } & \multirow{2}{*}{$\begin{array}{c}\boldsymbol{p} \text { - } \\
\text { myocytes cells }\end{array}$} \\
\cline { 3 - 5 } & & $\overline{\mathbf{x}}$ rank & SD & Min & Max & \\
\hline v0 & 7 & $4.57^{\mathrm{a}}$ & 1.45324 & 0.00 & 2.50 & \\
P1 & 7 & $16.07^{\mathrm{b}}$ & & 3.00 & 4.50 & \multirow{2}{*}{$0.001^{*}$} \\
P2 & 7 & $12.36^{\mathrm{b}}$ & & 2.00 & 4.50 & \\
\hline
\end{tabular}

Note: *significance $\alpha=0.05$ (Kruskal Wallis)

${ }^{\mathrm{a}, \mathrm{b}}$ It showed differences among the group (Mann-Whitney test)

There was a significant difference in the hypertrophy of myometrial myocyte cells ( $p<0.05$ ) (Table 2) between the control group compared to the treatment groups treated a $100 \mathrm{mg} / \mathrm{kg}$ bw/day and $150 \mathrm{mg} / \mathrm{kgbw} /$ day dose of Anastatica hierochuntica L. extract. However, there was no significant difference between the treatment groups in the hypertrophy of myocyte cells.

The average PGE2 level within the control group treated $0.5 \% \mathrm{CMC}$ and the treatment group treated with $A$. hierochuntica L. extract presented in Figure 2.

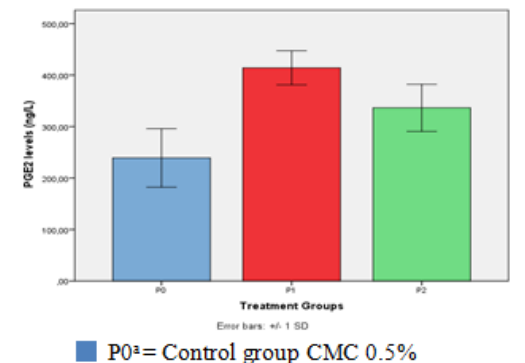

$\mathrm{P}^{\mathrm{C}}=$ Treatment group treated an AH dose of $100 \mathrm{mg} / \mathrm{kg}$ body weight $/$ day $\mathrm{P} 2^{\mathrm{b}}=$ Treatment group treated an AH dose of $150 \mathrm{mg} / \mathrm{kg}$ body weight/day $\mathrm{a}, \mathrm{b}, \mathrm{c}$ superscript showed difference among groups (multiple comparisons LSD)

Figure 2 The PGE2 level among groups.

Figure 2 shows that the PGE2 levels in group P1 $(100 \mathrm{mg} / \mathrm{kg}$ bw/day) increased $1.7 \times(\mathrm{X} 1=414.36)$ and in group P2 $(150$ $\mathrm{mg} / \mathrm{kg}$ bw/day $) 1.4 \times(\mathrm{X} 2=336.50)$ higher than the control group (X0 $=239.14)$. Group P1 also had PGE2 levels that were $1.2 \times$ higher than group P2. Furthermore, Table 3 presents the results of the one-way ANOVA test that was performed, with $\alpha=0.05$.

Table 3. ANOVA Test of PGE2 Level among the Groups.

\begin{tabular}{ccccccc}
\hline \multirow{2}{*}{ Groups } & \multirow{n}{*}{$\mathbf{n}$} & \multicolumn{2}{c}{ PGE2 level } & \multicolumn{4}{c}{$\boldsymbol{p}$-value } & \\
\cline { 3 - 6 } & & $\overline{\mathbf{x}}$ & SD & Min & Max & \\
\hline P0 & 7 & $239.14^{\mathrm{a}}$ & 56.76 & 177.00 & 343.50 & \\
P1 & 7 & $414.36^{\mathrm{c}}$ & 32.99 & 388.00 & 479.00 & $0.000^{*}$ \\
P2 & 7 & $336.50^{\mathrm{b}}$ & 45.83 & 266.00 & 402.50 & \\
\hline
\end{tabular}

Note: *significance $\alpha=0.05$ (one-way ANOVA)

a,b,c superscript showed difference among group (multiple comparisons LSD)

The results displayed in Table 3 presented that Anastatica hierochuntica L. treatment affects the PGE2 levels within pregnant mice. The significance level of PGE2 levels among the control group, group P1 (100 mg/kg bw/day), and group P2 (150 mg/kg bw/day) (P2), through one-way ANOVA statistical analysis, showed a significance level with $\mathrm{p}=0.000(\mathrm{p}<0.05)$. This result means there were significant differences in the levels of PGE2 between the control group and the treatment group. The results of the post-hoc tests, multiple comparisons of LSD, showed that there was a significant difference in the levels of PGE2 between the control group and group P1, the control group and group $\mathrm{P} 2$, and between the $\mathrm{P} 1$ and $\mathrm{P} 2$ groups.

The average level of PGF $2 \alpha$ between the control group, group P1, and group P2 is presented in Figure 3. 


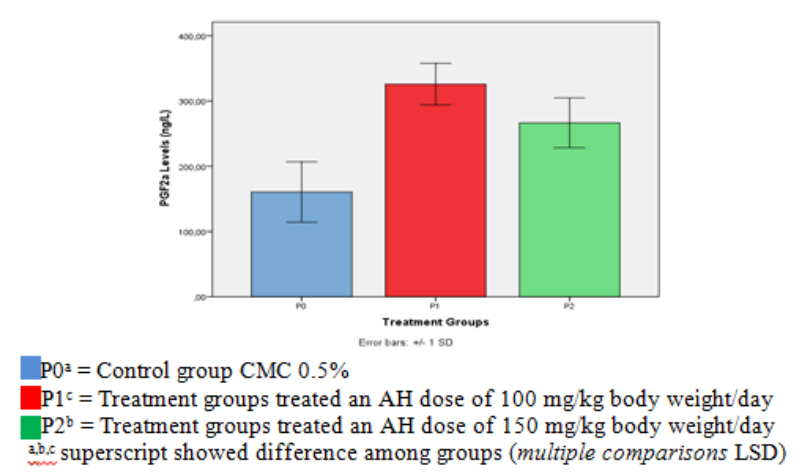

Figure 3. Level of PGF2 $\alpha$ among groups.

Figure 3 shows that the average level of PGF2 $\alpha$ withingroup P1 (100 mg/kgb w/day) and group P2 (150 mg/kg bw/day $)$ increased $2 \times(\mathrm{X} 1=325.76)$ and $1.6 \times(\mathrm{X} 2=$ 266.57), respectively, and both groups had higher levels than the control group $(\mathrm{X} 0=160.54)$. Whilst, the levels in group P1 was $1.2 \times$ higher than group P2. Furthermore, Table 4 shows the results of the one-way ANOVA $(\alpha=$ $0.05)$.

Table 4. ANOVA Test of PGF2 $\alpha$ Levels among Groups.

\begin{tabular}{|c|c|c|c|c|c|c|}
\hline \multirow{2}{*}{ Group } & \multirow{2}{*}{$\mathbf{n}$} & \multicolumn{4}{|c|}{ PGF2 $\alpha$ level } & \multirow{2}{*}{$p$-value } \\
\hline & & $\bar{x}$ & SD & Min & Max & \\
\hline P0 & 7 & $160.54^{\mathrm{a}}$ & 46.22 & 99.70 & 228.00 & \\
\hline P1 & 7 & $325.76^{c}$ & 31.95 & 298.70 & 391.00 & $0.000^{*}$ \\
\hline P2 & 7 & $266.57^{\mathrm{b}}$ & 38.17 & 206.00 & 301.70 & \\
\hline
\end{tabular}

Note: *significance $\alpha=0.05$ (one-way ANOVA)

a,b,c superscript showed difference among groups (multiple comparisons LSD)

The results in Table 4 demonstrated $A$. hierochuntica $\mathrm{L}$. did have an effect on the PGF2 $\alpha$ within pregnant mice. The level of significance of the difference in PGF2 $\alpha$ levels between the control group and the A.hierochuntica L. extract treatment group was $\mathrm{p}=0.000$ ( $\mathrm{p}<0.05$ ), demonstrating that there were significant differences of the levels of PGF $2 \alpha$ between the control group and the treatment group. The results of the post-hoc tests, multiple comparisons of LSD, demonstrated that there were significant differences in PGF2 $\alpha$ levels between the control group and the treatment group, and between treatment groups (P1 and P2).

Hypertrophy of myometrial myocyte cells occurs physiologically within pregnancy. It is associated with increased myometrial growth during late pregnancy. Smooth muscle cell hypertrophy is caused by the mechanical stretch of uterine tissue due to fetal growth [27]. However, the estrogen hormone also has an essential role within the growth of reproductive tissue cells, including the myometrium.

As explained in the previous studies, estrogen stimulation can cause hypertrophy at the end of pregnancy. Several potential mechanisms that regulate myometrial hypertrophy have been proposed within the literature. It has been reported that ovarian hormones, estrogen, and progesterone, could induce myometrial hypertrophy [27]. Phytochemical test results, using the LCMS method, presented that $A$. hierochuntica L. contained flavonoid compounds. Therefore, it is considered to be a phytoestrogen, which is structurally and functionally similar to estradiol, [15][29] with estrogenic function [30].

The administration of $A$. hierochuntica $\mathrm{L}$. affects the increased number of hypertrophic myometrial myocytes cells. The results showed that $A$. hierochuntica L. extract increased hypertrophic myometrial myocyte cells in pregnant mice, which was characterized by a bigger cell size ( $7 \mu \mathrm{m}-12 \mu \mathrm{m})$ compare to the control group $(4 \mu \mathrm{m}-6 \mu \mathrm{m})$. Moreover, it also increased the number of hypertrophic myocyte cells $36-50 \%$ of all observed myocytes. Based on these results, it obtained that the A. hierochuntica L. plant has the potential to induce myometrial cell hypertrophy at the end period of pregnancy. This change in process is normal since, physiologically, uterine tissue undergoes dynamic changes in the histological structure based on estrogen hormone levels [18]. Based on the study of Gaete et al., the administration of Genistein $(0.5 \mathrm{mg} / \mathrm{kg}$ body weight, subcutaneously) causes myometrial cell hypertrophy and uterine luminal epithelium as estradiol [31]. During hypertrophy, the contractile element enlarges and the extracellular matrix expands for growth [32].

The administration of Anastatica hierochuntica L. extract also increased the mean PGE2 and PGF2 $\alpha$ levels within the blood serum of pregnant mice. The administration of 100 $\mathrm{mg} / \mathrm{kgbw} /$ day of Anastatica hierochuntica L. extract increased the levels of PGE2 and PGF $2 \alpha$ by 1.7 and $2 \times$, respectively, compared to the control group. The results following the previous theory that estrogen and progesterone involve in regulating uterine contractions. The membrane is depolarized, increasing the prostaglandin production of PGE2, PGF $2 \alpha$, and oxytocin receptors. ${ }^{33}$ Previous research stated that prostaglandin F2 $\alpha$ increased in the proestrus phase of the rat cycle when estrogen levels were maximum.

This result proved that estradiol-17 $\beta$ caused an increase in prostaglandin F2 $\alpha$ levels in uterine ovariectomized rats. Estrogen acts to control prostaglandin synthesis by regulating the prostaglandin synthetase complex, as it produces a pattern change in the ratio of prostaglandin $\mathrm{F}$ to prostaglandin E [34].

The Anastatica hierochuntica L. treatment presented a significant difference in PGE2 levels (Table 3) and PGF2 $\alpha$ levels (Table 4). These results indicated that the 100 $\mathrm{mg} / \mathrm{kgbw} /$ day dose was more effective to induce the PGE2 and PGF $2 \alpha$ levels within pregnant mice. Increased levels of prostaglandin are expected to be related to cell hypertrophy and the stretching process (Mechanical Stretch) that has an impact on NFkB activation [35]. The NFkB activation process will trigger prostaglandin production via the Cox-2 pathway [36]. The results in this study showed that the administration of Anastatica hierochuntica L. extracts at doses of $100 \mathrm{mg} / \mathrm{kg}$ bw/day and $150 \mathrm{mg} / \mathrm{kgbw} /$ day increased prostaglandin levels compared to the control group-according to the increase of myometrial cell hypertrophy in the group. The association of an increase in prostaglandins, with myometrial cell hypertrophy, needs further analysis. 
antioxidant flavonoids , chlorogenic acids and phenolic compounds. Phytochemistry. 2011; 72(2-3): 248-254.

[7] Gamal EEG, Khalifa SAK, Gameel AS, Emad MA. Traditional medicinal plants indigenous to Al-Rass province, Saudi Arabia. J. Med. Plants Res. 2010; 4(24): 2680-2683.

[8] Baker RK, Ali BH, Jameel NM. The Effect Of Aqueous Extract Of Anastatica Hierochuntica On Some Hormones In Mouse Females. Ibn Al-Haitham J. Pure Appl. Sci. 2013; 26(2): 198-205.

[9] Daur I. Chemical properties of the medicinal herb Kaff Maryam ( Anastatica hierochuntica L .) and its relation to folk medicine use. African J. Microbiol. Res. 2012; 6(23): 5048-5051.

[10] Mohamed AA, Khalil AA, El-beltagi HES. Antioxidant and antimicrobial properties of kaff maryam ( Anastatica hierochuntica L.) and doum palm (Hyphaene thebaica). Grasas Y Aceites. 2010; 61(1):67-75.

[11] Rizk A, Hammouda F, Ismail S, Hassan NM. Constituents of Plants Growing in Qatar XX. Phytochemical Investigation of Anastatica hierochuntica. Intrnational J. Pharmacog. 1993; 31(4): 327-329.

[12] Breinholt V, Hossaini A, Svendsen GW, Brouwer C, Nielsen E. Estrogenic Activity ofrelate to kerstingiella geocarpa. Food Chem. Toxicol. 2000; 38: 555-564.

[13] Shah AH, Bhandari MP, Al-harbi NO, Al-ashban RM. Kaff-E-Maryam (Anastatica hierochuntica L .): Evaluation of Gastro-Protective Activity and Toxicity in Different Experimental Models. Biol. Med. 2014; 6(1): 1-10.

[14] Daoowd WS. In vitro antifungal activity of extracts of Anastatica Hierochuntica. or Vet. Med. Sci. 2013; 4(1): 142-148.

[15] Zhao E. Mu Q. Phytoestrogen biological actions on mammalian reproductive system and cancer growth. Sci. Pharm. 2011; 79(1): 1-20.

[16] Ilicic M, Paul JW. Methods and Model Systems Used to Study Pregnant Human Uterine Smooth Muscle. Muscle Cell Tissue - Curr. Status Res. F. 2018; 15: 309-335.

[17] Lecomte S, Demay F, Ferrière F, Pakdel F. Phytochemicals targeting estrogen receptors: Beneficial rather than adverse effects. Int. J. Mol. Sci. 2017; 18(7): 119.

[18] Weihua Z, Saji S, Mäkinen S, Cheng G, Jensen EV, Warner M, Gustafsson JA. Estrogen receptor (ER) beta , a modulator of ERalpha in the uterus. Proc. Natl. Acad. Sci. 2000; 97(11): 5936-5941.

[19] Kota SK, Gayatri K, Jammula S, Kota SK, Krishna SVS, Meher LK, Modi KD. Endocrinology of parturition. Indian J. Endocrinol. Metab. 2013; 17(1): 50-59.

[20] Challis JR, Sloboda DM, Alfaidy N, Lye SJ, Gibb W, Patel FA, Whittle WL, Newnham JP. Prostaglandins and mechanisms of preterm birth. Reproduction. 2002; 124(1): $1-17$. 221.

[22] Ricciotti E, Fitzgerald GA. Prostaglandins and
[21] Safdar AA, Kia DH, Farhadi R. Physiology of parturition. Int. J. Adv. Biol. Biomed. Res. 2013; 1(3): 214- 
Inflammation. Arter. Thromb Vasc Biol. 2011; 31(5): 9861000 .

[23] Woodward DF, Jones RL, Narumiya S. International Union of Basic and Clinical Pharmacology . LXXXIII : Classification of Prostanoid Receptors, Updating 15 Years of Progress. Pharmacol. Rev. 2011; 63(3): 4710538.

[24] Sobhy EA, Tailang M, Benyounes S, Gauthaman K. Antimalarial and hepatoprotective effects of entire plants of Anastatic hierochuntica. Int. J. Res. Phytochem. Pharmacol. 2011; 1(1): 24-27.

[25] Rahman AM, Yusuf SW, Ewer MS. Anthracyclineinduced cardiotoxicity and the cardiac-sparing effect of liposomal formulation. Int. J. Nanomedicine. 2007; 2(4): 567-538.

[26] Challis JRG, Matthews SG, Gibb W, Lye SJ. Endocrine and paracrine regulation of birth at term and preterm. Endocr. 2000; 21(5): 514-550.

[27] Shynlova O, Kwong R, Lye SJ. Mechanical stretch regulates hypertrophic phenotype of the myometrium during pregnancy. Reproduction. 2010; 193: 247-253.

[28] Young RC. Myocytes, myometrium, and uterine contractions. Ann. N. Y. Acad. Sci. 2007; 1101: 72-84.

[29] Eden JA. Maturitas Phytoestrogens for menopausal symptoms : A review. Maturitas. 2012; 72(2): 157-159.

[30] Lissin LW, Cooke JP. Phytoestrogens and Cardiovascular Health. J. Am. Coll. Cardiol. 2000; 35(6): 1403-1410.

[31] L. Gaete, Tchernitchin A, Rodrigo B, Villena J. Biological Activity of Genistein and Soy Extracts: Selective Induction of some but not all Estrogenic Responses in the Prepubertal Rat Uterus. Boletín Latinoam. y del Caribe Plantas Med. y Aromáticas. 2010; 9(4): 302311.

[32] Schoenfeld BJ. The Mechanisms Of Muscle Hypertrophy And Their Application To Resistance Training. J. Strength Cond. Res. 2010; 24(10): 2857-2872.

[33] Jain V, Saade GR, Garfield RE. Uterine Contraction. Encycl. Reprod. 1999; 4(January): 932-942.

[34] Ham EA, Cirillo V J, Zane1ti ME, Kuehl FA. Estrogen-Directed Synthesis of Specific Prostaglandins in Uterus. Med. Sci. 1975; 72(4): 1420-1424.

[35] Lindstro TM, Bennett PR. The role of nuclear factor kappa B in human labour. Reproduction. 2005; 130: 569581.

[36] Syamsul BJ E, Riva'i, Darwin E, Nasrul E. Role of nuclear factor kappa beta, tumor necrosis factor $\alpha$, and cyclooxygenase-2 in preterm labor. Med J Indones. 2014; 23(4): 213-217.

[37] Carbonne B. Cervical maturation and labor induction. Hypertens. Res. Pregnancy. 2014; 2: 59-64. 